\title{
The thermal state and strength of the lithosphere in the Spanish Central System and Tajo Basin from crustal heat production and thermal isostasy
}

\author{
Alberto Jiménez-Díaz ${ }^{\mathrm{a}, \mathrm{b}, *}$, Javier Ruiza ${ }^{\text {, Carlos Villaseca }}{ }^{\mathrm{b}, \mathrm{c}}$, Rosa Tejero ${ }^{\mathrm{a}, \mathrm{b}}$, Ramón Capote ${ }^{\mathrm{a}}$

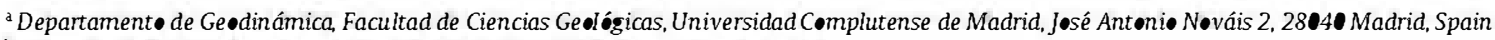

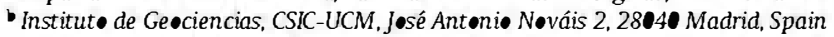

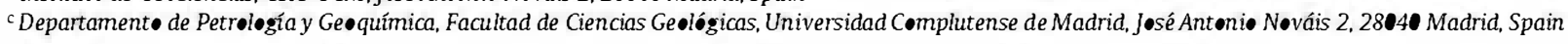

Keywords:

Heat flow

Thermal structure

Strengthenvelopes, Rheology

Continentallithosphere

lberian Peninsula

\begin{abstract}
A B S T R A C T

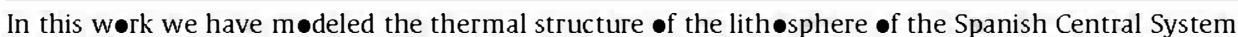

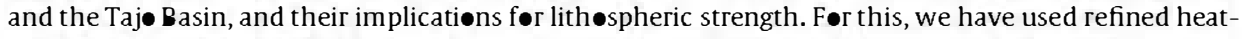

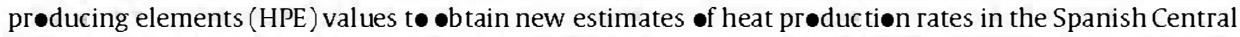

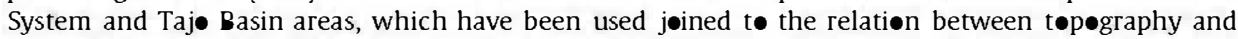

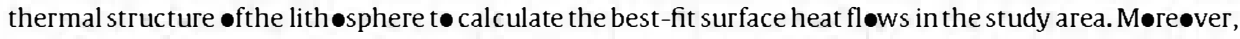

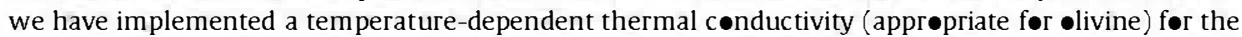

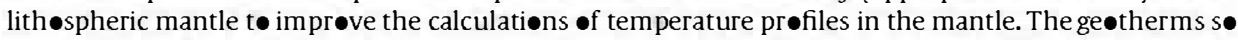
-btained, together with the implementation of a new rheøløgical law for the upper lithøspheric mantle, have been used t• calculate refined estimations of the strength and effective elastic thickness $\bullet$ the lith $\bullet$ spere. We have $\bullet$ btained surface heat fl $\bullet$ values of $84 \mathrm{~mW} \mathrm{~m}^{-2}$ and $\sim 82 \mathrm{~mW} \mathrm{~m}^{-2}$ for the Spanish Central System and the Taj• Basin, respectively. The thermal state of the lithøsphere affects mantle temperatures, and hence may be playing an imp•rtant røle in the uplift and maintenance of the Spanish Central System.
\end{abstract}

\section{Introduction}

The thermal state and the rheological behavior of the continental lithosphere depend on many factors (e.g., Afonso and Ranalli, 2004; Chapman and Furlong, 1992; Kohlstedt et al., 1995; Ranalli, 1997; Ranalli and Murphy, 1987). Due to the relationship between thermal and mechanical structure of the lithosphere, it is necessary to have an adequate knowledge of the thermal parameters, local heat flow and thermal structure, to reduce the uncertainty in strength estimates. For example, the amount and distribution of lithospheric heat-producing elements (HPE) and the values of the thermal conductivities of crust and mantle may affect the results substantially. Thus, the mechanical behavior and rheological stratification of the lithosphere in continental areas are largely a consequence of local conditions (e.g., Afonso and Ranalli, 2004; Furlong and Chapman, 1987; Ruiz et al., 2006; Watts and Burov, 2003). On the other hand, recent laboratory experiments conducted under controlled microstructural and chemical conditions have shown a significant effect of important parameters on

\footnotetext{
* Corresponding author at: Departamento de Geodinámica, Facultad de Ciencias Geológicas, Universidad Complutense de Madrid, José Antonio Nováis 2, 28040 Madrid, Spain.

E-mail address: ajimenezdiaz@geo.ucm.es (A. Jiménez-Díaz).
}

the rheological properties of major silicate rocks (Bürgmann and Dresen, 2008), and have yielded new rheological laws describing the first-order mechanical behavior of the lithospheric materials (e.g., Katayama and Karato, 2008; Keefner et al., 2011; Mei et al., 2010).

The aim of this work is to model the thermal structure and their implications for lithospheric strength of the Spanish Central System (SCS) and the Tajo Basin (TB). The SCS constitutes the most prominent topographic elevation in the interior of the Iberian Peninsula separating the Duero and Tajo watersheds. It is flanked by two Cenozoic intracontinental sedimentary basins, the Duero Basin to the north and the TB to the south (Fig. 1). The SCS is a thick-skinned double-vergence (pop-up) intraplate range built as a result of polyphase Alpine tectonic evolution (De Vicente and Vegas, 2009; De Vicente et al., 2004, 2007, 2009; Fernández-Lozano et al., 2011; Martín-Velázquez et al., 2009), in which the deformation partitioning of the basement in the intraplate convergence setting of Iberia has had a profound influence on the development of topography.

The surface heat flow map of the Iberian Peninsula performed by Fernàndez et al. (1998) provides some values at the SCS-TB boundaryand the north and south of the TB. In contrast, the SCS is not well characterized due to the unavailability of heat flow measurement, and it is necessary to approach the study of the thermal state of the range through other methodologies. In this sense, Tejero and Ruiz 


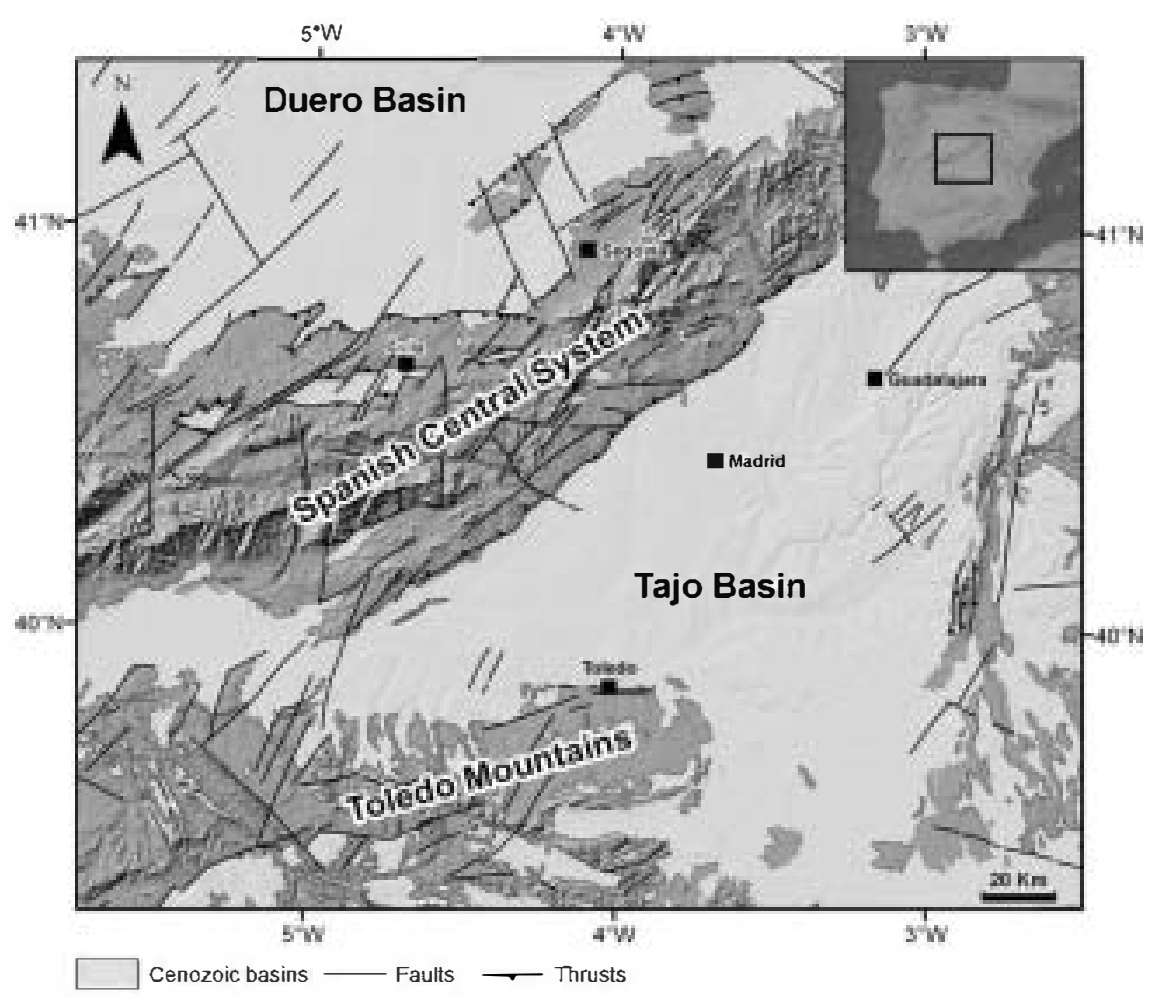

Fig. 1. Geographical andgeological settings of the study area showing the two mountains ranges (Spanish Central System and Toledo Mountains) separated by the Tajo Basin Map background is from the Neotectonic Map of Spain (IGME and ENRESA, 1998).

(2002) modeled the thermal structure of the lithosphere of this area by using thermal isostasy to improve the calculated geotherms, considering surface heat flow values of 70 and $65-70 \mathrm{~mW} \mathrm{~m}^{-2}$ for the SCS and the TB, respectively.

On the other hand, several works have focused on characterizing the lithospheric strength from estimating the effective elastic thickness of the lithosphere through flexure modeling (Van Wees et al., 1996), the coherence between topography and Bouguer anomaly (Gómez-Ortiz et al., 2005a; Pérez-Gussinyé and Watts, 2005) or from rheological models (Martín-Velázquez et al., 2008; Ruiz et al., 2006; Tejero and Ruiz, 2002; Tesauro et al., 2007, 2009).

In the present work, we have used the relation between topography and thermal structure to calculate the best-fit surface heat flows. We included a temperature-dependent thermal conductivity (appropriate for olivine) for the lithospheric mantle to improve the calculations. Moreover, we have used refined HPE values based on bulk rock composition of main lithological formations of the SCS and the Toledo Mountains (e.g. Villaseca et al., 1998, 1999, 2005; this study), and these values have been used to obtaining estimates of heat production rates. Finally, we have used our result for the thermal structure in order to analyze the strength of the lithosphere in the study area. To make this, we have implemented a new rheological law for the upper lithospheric mantle, largely controlled by low-temperature plasticity of olivine-rich rocks (Mei et al., 2010). All of this provides an opportunity to refine existing thermal and rheological models and lithospheric strength determinations of the study area.

\section{Temperature profiles}

The thermal structure of the lithosphere depends on heat flow, heat sources distribution and thermal conductivity of lithospheric rocks. The temperature profile within the lithosphere has been calculated assuming steady-state conditions and radioactive heat sources homogeneously distributed in three crustal layers and in the lithospheric mantle. The temperature at depth $z$ in each crust layer is

$T_{z}=T_{s}+\frac{F_{S} z}{k}-\frac{H z^{2}}{2 k}$,

where $T_{s}$ and $F_{s}$ are the temperature and heat flow at the layer top, $k$ is the thermal conductivity, and $H$ is the volumetric heat production rate. The calculations assume $k=2.5,2.5$ and $2.1 \mathrm{~W} \mathrm{~m}^{-1} \mathrm{~K}^{-1}$ for upper, middle and lower crust, respectively, and the surface temperature was taken as $288 \mathrm{~K}$.

The thermal conductivity of olivine (the main mineral in the mantle) is strongly temperature-dependent; therefore temperature profiles in the mantle lithosphere are calculated from (see Ruiz et al., 2011)

$\frac{d T}{d z}=\frac{F_{c}-m_{m} H_{m}\left(z-b_{c}\right)}{k_{m}(T)}$,

where $F_{c b}=F-{ }_{c} H_{c} b_{c}$ is the heat flow at the base of the crust, $m$ and $H_{m}$ are, respectively, the density and heat production rate per mass unity of the mantle lithosphere, $b_{c}$ is the base of the crust, and $k_{m}$ is the thermal conductivity of the mantle lithosphere. For $k_{m}$ we use the thermal conductivity of olivine, which is a function of temperature according to the expression (McKenzie et al., 2005)

$k_{\mathrm{m}}=\frac{a}{1+c(T-273)}+\sum_{i=0}^{3} d_{i} T^{i}$,

where $a=5.3, c=0.0015, d_{0}=1.753 \times 10^{-2}, d_{1}=-1.0364 \times 10^{-4}$, $d_{2}=2.2451 \times 10^{-7}$ and $d_{3}=-3.4071 \times 10^{-11}$. Results obtained from Eq. (3) are similar to those of Hofmeister (1999) for forsterite olivine. For solving Eqs. (2) and (3), we used the Newton iterative method.

Moreover, the use of concept of thermal isostasy is useful in order to constrain continental temperature profiles (e.g., Fernàndez et al., 1998; Hasterok and Chapman, 2007, 2011; Lachenbruch and 
Morgan, 1990; Tejero and Ruiz, 2002), by providing a link between the thermal structure of the lithosphere and the elevation of the surface. Elevation above sea level (e) can be expressed by

$e=h_{c}+h_{m}-h_{0}$

where $h_{c}$ and $h_{m}$ are the individual contributions of crust and mantle components to the buoyancy of the lithosphere. $h_{\bullet}$ is the buoyant height of sea level above the free asthenosphere surface ( $h_{\bullet} \approx 2.4 \mathrm{~km}$; Lachenbruch and Morgan, 1990). Crust contribution is estimated from

$h_{c}=\frac{1}{p_{a}}\left(\omega_{a}\right) b_{c}$,

where $b_{c}$ is crust thickness, $\boldsymbol{\rho}_{c}$ is mean crust density and $\boldsymbol{\rho}_{a}$ is asthenosphere density $\left(3200 \mathrm{~kg} \mathrm{~m}^{-3}\right.$ ). Mantle contribution is related to the thermal state of the lithosphere mantle by

$h_{m}=a\left(\bar{T}_{m}-T_{a}\right) b_{m}$,

where $\boldsymbol{\alpha}$ is the thermal volumetric expansion coefficient $\left(3.5 \times 10^{-5} \mathrm{~K}^{-1}\right), b_{m}$ is the thickness of the lithospheric mantle until the asthenosphere temperature $T_{a}$, assumed to be the isotherm of $1350^{\circ} \mathrm{C}$, and $\bar{T}_{\mathrm{m}}$ is the mean lithosphere mantle temperature given by

$\bar{T}_{m}=\frac{1}{b_{m}} \int_{0}^{b_{m}} T(z) d z$,

which we use here in order to determine the depth of the lithosphere-asthenosphere boundary $(L A B)$. Here we use crustal structure and composition derived from seismic data (Banda et al., 1981; ILIHA DSS Group, 1993; Suriñach and Vegas, 1988), and crustal density derived from gravity data analysis (Gómez-ortiz et al., 2005b). Mantle heat flow was estimated by subtracting crustal contribution from surface heat flow. We applied the thermal isostasy model by iterative calculation to fit the calculated elevation to the observed mean elevation ( $\sim 1250 \mathrm{~m}$ and $\sim 650 \mathrm{~m}$ for SCS and TB, respectively). Table 1 summarizes the parameters used in the calculations.

\section{Crustal heat production}

Uranium, Thorium and Potassium (collectively termed as heatproducing elements, HPE) abundance determines heat production rates of crustal rocks. Thus, heat production is calculated from HPE abundance by the addition of the contribution of each element as follows (Rybach, 1988)

$H\left(\mu \mathrm{W} \mathrm{m}{ }^{-3}\right)=10^{-5} \cdot\left(9.52 C_{\mathrm{U}}+2.56 C_{\mathrm{Th}}+3.48 C_{\mathrm{K}}\right)$,

where $C_{\mathrm{U}}$ and $C_{\mathrm{Th}}$ are in ppm and $C_{\mathrm{K}}$ in percent, and $\rho$ is the density (in $\mathrm{kg} \mathrm{m}^{-3}$ ). This method has been used to estimate heat production rates of the crust of Central Iberia (Spain), where 196 samples of metamorphic and igneous rocks of Variscan basement were collected and their content on HPE determined. They represent main outcropping lithologies mostly orthogeneiss and granites. Furthermore, granulite xenoliths carried by Upper Permian alkaline lamprophyres have been interpreted as samples of the lower crust below the SCS (Villaseca et al., 1999). Table 2 summarizes HPE abundances collected from 196 sites covering the Spanish Central System and the Toledo Mountains.

HPE abundances and heat production values for the SCS complex comprises outcropping metamorphic rocks mostly of two types: metasedimentary sequences and felsic orthogneissic rocks. These Cambrian-Lower Ordovician metaigneous rocks are the dominant country rocks, and they show higher heat production rates than metasedimentary types because they are enriched in $U$ and $\mathrm{K}$ (Table 2). Metabasic rocks have been also described in the SCS,

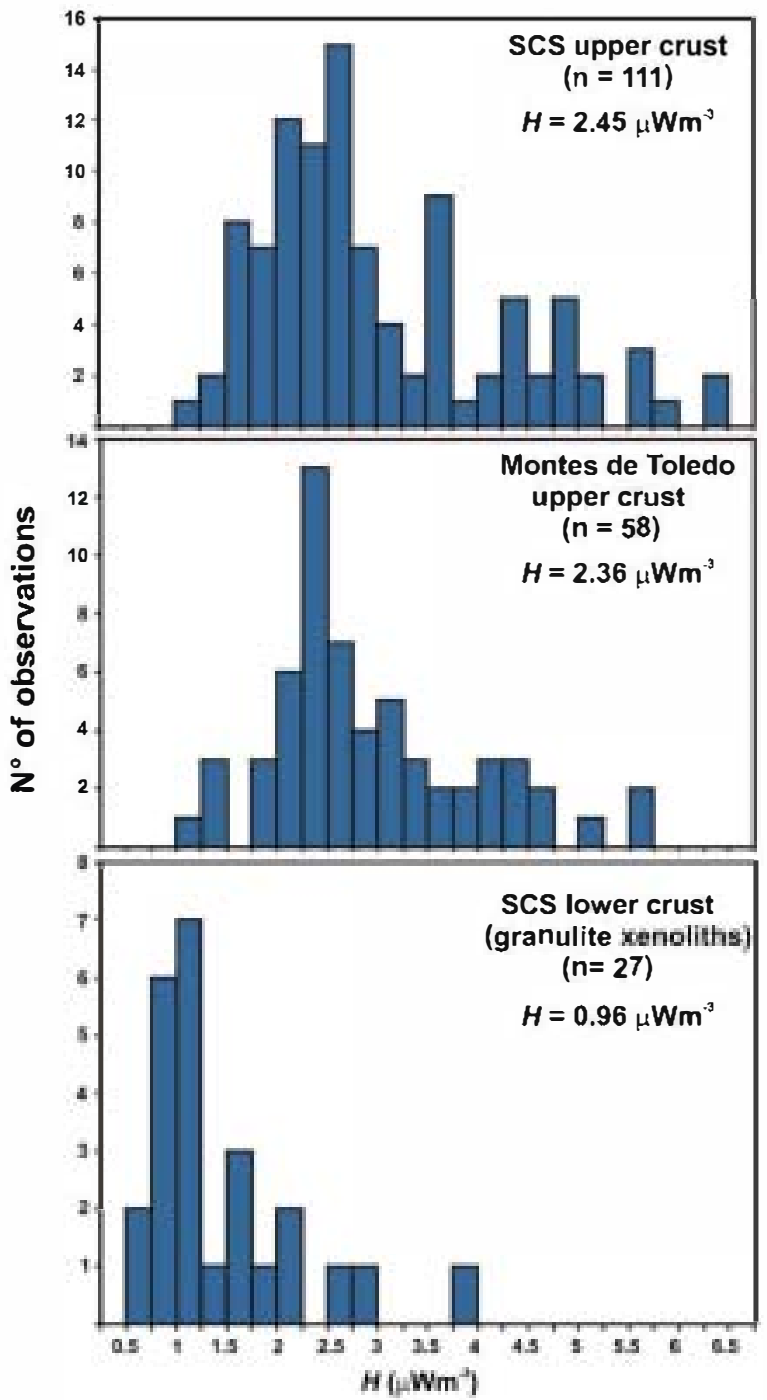

Fig. 2. Estimates of heat production rates of rocks from the Spanish Central System upper crust, Toledo Mountains upper crust and Spanish Central System lower crustal granulite xenoliths.

but defining a very minor surface; regional geologic maps suggest that felsic orthogneisses constitute approximately the $80 \%$ of the metamorphic rock exposures at least in his eastern half sector. Otherwise, most of the SCS is occupied by a huge granitic batolith. Proportions determined by mapped lithologies suggest that granites might be $75 \%$ of the SCS. The SCS Variscan granites are characterized by an averaged heat production of $2.49 \mu \mathrm{W} \mathrm{m}^{-3}$ (pondered by granite type and area, Table 2), higher values than those of orthogneissic wall-rocks. This approach yields an averaged heat production value of $2.45 \mu \mathrm{Wm}^{-3}$ for the outcropping SCS rocks (Fig. 2).

In the south, Toledo Mountains is also comprised by metamorphic rocks intruded by Variscan granite plutons. Country rocks are dominated by Neoproterozoic-Low Palaeozoic metasedimentary sequences (the Schist-Greywacke Complex), most of low-grade metamorphism (San José et al., 1990). The estimated average heat production rate of $2.36 \mu \mathbf{W ~ m}^{-3}$ (Table 2 and Fig. 2) for the whole Toledo Mountains area is lower to that obtained for the whole granite-high-grade metamorphic complex of the SCS, mostly due to the lower abundance of granites in the Toledo Mountains area (Table 2). HPE abundances for Tajo sedimentary rocks are not available, although representative heat production rates can be estimated from the surrounding orogenic areas as their 


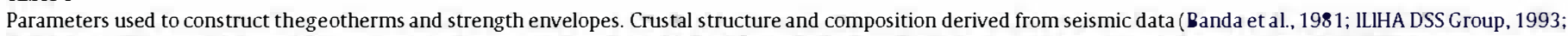
Suriñach and Vegas, 1988), crustal density derived from gravity data analysis (Gómez-Ortiz et al., 2005b) and rheological parameters from Ranalli (1997).

\begin{tabular}{|c|c|c|c|c|c|c|c|}
\hline & Thickness (km) & $\begin{array}{l}\text { Thermal conductivity } \\
\left(\mathrm{W} \mathrm{m}^{-1} \mathrm{~K}^{-1}\right)\end{array}$ & $\begin{array}{l}\text { Heat production } \\
\left(\mu W_{m^{-3}}\right)\end{array}$ & Density $\left(\mathrm{kgm}^{-3}\right)$ & $A\left(\mathrm{MPa}^{-n} \mathrm{~s}^{-1}\right)$ & $\mathbf{e}\left(\mathrm{kJ} \mathrm{mol}^{-1}\right)$ & $n$ \\
\hline \multicolumn{8}{|l|}{ Spanish Central System } \\
\hline Upper crust (dry granite) & 11 & 2.5 & 2.45 & 2670 & $1.8 \times 10^{-9}$ & 123 & 3.2 \\
\hline Upper crust (wet granite) & & & & & $2.0 \times 10^{-4}$ & 137 & 1.9 \\
\hline Middle crust (quarzdiorite) & 14 & 2.5 & 1.75 & 2800 & $1.3 \times 10^{-3}$ & 219 & 2.4 \\
\hline Lower crust (felsic granulite) & 9 & 2.1 & 0.96 & 2900 & $8.0 \times 10^{-3}$ & 243 & 3.1 \\
\hline \multicolumn{8}{|l|}{ Tajo Basin } \\
\hline Sediments layer & $2 / 1^{\mathrm{a}}$ & 2.5 & 2.40 & 2400 & $6.7 \times 10^{-6}$ & 156 & 2.4 \\
\hline Upper crust (dry quarzite) & $12 / 13^{a}$ & 2.5 & 2.36 & 2780 & $6.7 \times 10^{-6}$ & 156 & 2.4 \\
\hline Upper crust (wet quarzite) & & & & & $3.2 \times 10^{-4}$ & 154 & 2.3 \\
\hline Middle crust (quarzdiorite) & 9 & 2.5 & 1.65 & 2800 & $1.3 \times 10^{-3}$ & 219 & 2.4 \\
\hline Lower crust (felsic granulite) & 8 & 2.1 & 0.96 & 2900 & $8.0 \times 10^{-3}$ & 243 & 3.1 \\
\hline
\end{tabular}

a Thickness for north/south Tajo Basin, respectively.

sedimentary source regions (averaged heat production of $2.40 \mu \mathrm{Wm}^{-3}$; Table 1 ).

The averaged heat production rate of the lower crust is estimated to be $0.96 \mu \mathrm{Wm}^{-3}$; value slightly lower than preliminary estimates (Villaseca et al., 2005), but clearly higher than values usually considered for the lower crust (Furlong and Chapman, 1987; Hasterok and Chapman, 2011; Rudnick and Gao, 2003; Vilà et al., 2010). This is consequence of the markedly felsic composition of the SCS lower crust, dominated by felsic meta-igneous (95vol\%) and pelitic ( 5 vol\%) granulites (Villaseca et al., 1999). The felsic nature of the SCS lower crust is best shown in comparison with other lower-crustal xenoliths suites which, on average, are more mafic than granulite terranes (Villaseca et al., 1999 and references therein).

Heat production of the middle crust is not well characterized due to the unavailability of direct measurement, and thus, there is considerable uncertainty with regard to this parameter. The mid-crustal layer is not pervasive globally, and where it exists, tends to have radiogenic heat generation more similar to lower rather than to upper crust (Hasterok and Chapman, 2011 and references therein). On the other hand, the middle crust of the area is made of intrusive felsic materials (Villaseca et al., 1999) similar to those forming the upper crust in many continental areas, and seismic velocities findings point to a granodioritic composition of the middle crust (Banda et al., 1981). Unknown of the depth distribution of rocks compelled us to consider layer homogeneity, and we have assumed an intermediate (density weighted) heat production rate between upper and lower crust. Finally, for the lithospheric mantle we use a standard heat production rate of $0.02 \mu \mathbf{W ~ m}^{-3}$ (e.g., Chapman and Furlong, 1992; Hasterok and Chapman, 2011).

\section{Strength of the lithosphere}

The concept of strength envelopes is useful to illustrate a firstorder approximation of the rheological properties of lithosphere (e.g., Brace and Kohlstedt, 1980; Kohlstedt et al., 1995; Ranalli, 1997; Ranalli and Murphy, 1987). Thus, the strength of the lithosphere at any depth is the minimum between the strengths for brittle and ductile deformation. Assuming a prefractured medium with fractures ideally oriented, the brittle strength is calculated according to the expression (e.g., Ranalli, 1997; Ranalli and Murphy, 1987)

$\left(\sigma_{1}-\sigma_{3}\right)_{\mathbf{b}}=\beta \operatorname{\beta \rho g}(1-\lambda) z$,

where $\beta$ is a coefficient depending on the stress regime $(0.75$ for tension and 3 for compression), $p$ is the density, $g$ is the acceleration due to the gravity $\left(9.8 \mathrm{~m} \mathrm{~s}^{-2}\right), \lambda$ is the pore fluid factor defined as the ratio of pore fluid pressure to lithostatic pressure (Sibson, 1974), and $z$ the depth. The density of the brittle crust, adequate for rocksin the upper crust, is taken as $2670 \mathrm{~kg} \mathrm{~m}^{-3}$ fortheSCS and $2780 \mathrm{~kg} \mathrm{~m}^{-3}$ for the TB (Gómez-ortiz et al., 2005b). In addition, a sedimentary layer is considered in the TB (Table 1). We use the same hydrostatic pore fluid factor $(\lambda=0.37)$ for the whole lithosphere.

The ductile strength does not depend on the stress regime but it is strongly strain rate- and temperature-dependent (Burov and Diament, 1995; Ranalli and Murphy, 1987; Stüwe, 2002), and can be described by a thermally activated power law,

$\left(\sigma \quad(\dot{e})^{1 / n} \exp \left(\frac{\mathrm{Q}}{n R T}\right)\right.$,

where $\dot{e}$ is the strain rate, $A, Q$, and $n$ are laboratory-determined constants, $R$ is the gas constant $\left(8.31447 \mathrm{~J} \mathrm{~mol}^{-1} \mathrm{~K}^{-1}\right)$, and $T$ is the

Table 2

Estimates of heat production of rocks from the Spanish Central System and Toledo Mountains.

\begin{tabular}{|c|c|c|c|c|c|c|}
\hline & Area $(\%)$ & Numbers of samples & $\mathrm{U}(\mathrm{ppm})$ & Th (ppm) & $\mathrm{K}(\%)$ & $H\left(\mu \mathrm{W} \mathrm{m}^{-3}\right)$ \\
\hline \multicolumn{7}{|c|}{ Spanish Central System } \\
\hline \multicolumn{7}{|c|}{ Metamorphic rocks } \\
\hline Metabasites & $<0.1$ & 6 & 1.37 & 5.70 & 0.54 & 0.86 \\
\hline Metapelites & 20 & 8 & 2.65 & 14.82 & 2.76 & 2.00 \\
\hline Metagranites & 80 & 41 & 4.61 & 12.25 & 3.69 & 2.42 \\
\hline \multicolumn{7}{|l|}{ Granitic rocks } \\
\hline Monzogranites & 85 & 25 & 3.07 & 15.63 & 3.72 & 2.22 \\
\hline Leucogranites & 15 & 31 & 8.61 & 21.23 & 3.83 & 4.04 \\
\hline \multicolumn{7}{|c|}{ LC Granulite Xenoliths } \\
\hline Chamockites & $<1$ & 4 & 1.18 & 2.61 & 1.87 & 0.69 \\
\hline Pelites & 5 & 6 & 0.78 & 9.14 & 2.32 & 1.21 \\
\hline Metaigneous & 95 & 17 & 0.70 & 6.54 & 2.55 & 0.95 \\
\hline \multicolumn{7}{|l|}{ Toledo Mountains } \\
\hline Metasediments & 55 & 5 & 3.66 & 10.97 & 2.63 & 1.98 \\
\hline Granites MTB & 35 & 42 & 6.38 & 14.76 & 3.55 & 2.99 \\
\hline АСГ Migmatites & 10 & 11 & 3.39 & 12.88 & 4.97 & 2.27 \\
\hline
\end{tabular}


absolute temperature. Strength envelopes are calculated for a strain rate of $10^{-15} \mathrm{~s}^{-1}$.

The ductile strength of the upper crust is calculated using flow laws for wet/dry granite and wet/dry quartzite for the SCS and TB, respectively. The lower crust of the central Iberian Peninsula is of a felsic granulite nature (Villaseca et al., 1999), and bearing in mind its flow law it should not appreciably contribute to the strength of the lithosphere. It is therefore not taken into account in the present work (see Tejero and Ruiz, 2002; Ruiz et al., 2006). In turn, the middle crust of the area is made of intrusive felsic materials (Villaseca et al., 1999) similar to those forming the upper crust in many continental areas; its mechanical behavior is therefore likely to be similar (Ruiz et al., 2006).

For the estimation of the strength of the lithospheric mantle we use dry and wet olivine rheologies, which give upper and lower limits, respectively. The behavior of the upper lithospheric manthe is in turn largely controlled by low-temperature plasticity of olivine-rich rocks (Mei et al., 2010), resulting in a rheology significantly weaker than that usually used for the lithosphere mantle. Under anhydrous conditions, Mei et al. (2010) define a flow law for a quasi steady state deformation of olivine under low-temperature and high-stress, which can be written in terms of differential stress as

$\left(\begin{array}{ll}\sigma & \quad\end{array}\right)=\left(\begin{array}{c}\dot{e} \\ A_{k}\end{array}\right)^{1 / 2} \quad\left[\begin{array}{c}E_{k}(0) \\ 2 R T\end{array}\left(\begin{array}{ll}1 & \sqrt{\frac{\left(\sigma_{1}-\sigma_{3}\right)}{\sigma_{k}}}\end{array}\right)\right]$,

where $A_{p}=1.4 \times 10^{-7} \mathrm{~s}^{-1} \mathrm{MPa}^{-2}, E_{k}(0)$ is the zero-stress activation energy $\left(320 \pm 50 \mathrm{~kJ} \mathrm{~mol}^{-1}\right)$, and $\sigma_{p}$ is Peierls stress $(5.9 \pm 0.2 \mathrm{GPa})$. Thus, for dry olivine we use the minimum strength obtained from Eq. (11) and from the high temperature flow law obtained for artificially dried dunites: $A=28,840 \mathrm{MPa}^{-n} \mathrm{~S}^{-1}, n=3.6$ and $\mathrm{Q}=535 \mathrm{~kJ} \mathrm{~mol}^{-1}$ (Chopra and Paterson, 1984). For wet olivine, we use the flow law of the Anita Bay dunite: $A=9550 \mathrm{MPa}^{-n} \mathrm{~S}^{-1}$, $n=3.35$ and $\mathrm{Q}=444 \mathrm{~kJ} \mathrm{~mol}^{-1}$ (Chopra and Paterson, 1984). This flow law places a lower limit on the strength of wet olivine due to its relative weakness (compared with other wet dunites, such as Aheim dunite).

Finally, the total lithospheric strength (Ranalli, 1997) can be defined as

$S=\int_{0}^{b_{L}}\left(\sigma_{1}-\sigma_{3}\right)(z) d z$

where $(\sigma$

ductile strength, and $b_{L}$ is the mechanical thickness of the lithosphere. The base of the mechanical lithosphere is here defined as the depth at which the ductile strength reaches a low value of $10 \mathrm{MPa}$ (McNutt, 1984; Ranalli, 1994), and below which there are no further significant increases in strength, although the exact value selected does not produce significant changes in the calculations due to the exponential dependence of ductile strength on temperature. Table 1 summarizes the rheological model parameters.

\section{Results}

\subsection{Thermal modeling}

Fig. 3 shows the geotherms obtained by our thermal model. For the SCS, we have obtained a value of $F_{s}=84 \mathrm{~mW} \mathrm{~m}^{-2}$, with elevation adjustment of $\pm 1 \mathrm{~m}$ (Table 3 and Fig. 3 ). For the north and south TB, we have obtained values of $F_{s}=81 \mathrm{~mW} \mathrm{~m}^{-2}$ and $F_{s}=83 \mathrm{~mW} \mathrm{~m}^{-2}$ respectively, with elevation adjustment of $\pm 2 \mathrm{~m}$ in both cases (Table 3 and Fig. 3). We have calculated the surface heat flow from the thermal isostasy model obtaining through iterative calculation the surface heat flow best-fitting the observed mean elevation. In this sense, a heat flow uncertainty of $\pm 0.1 \mathrm{~mW} \mathrm{~m}^{-2}$

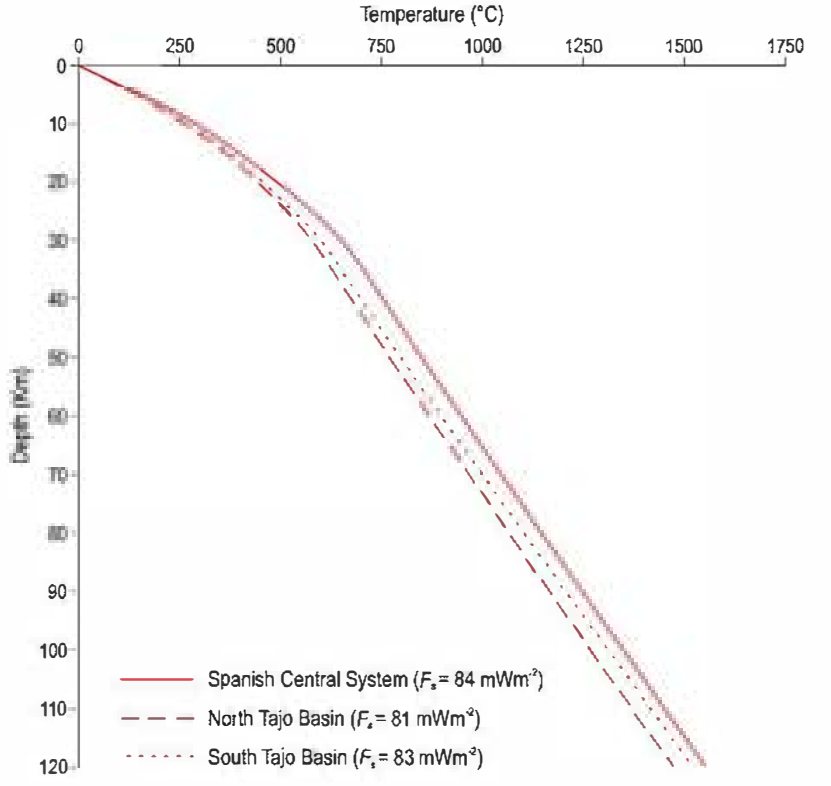

Fig. 3. Geotherm constructed for the Spanish Central System and the Tajo Basin. Variables used in estimations are provided in Table 1. See text for details.

and $\pm 0.01 \mathrm{~mW} \mathrm{~m}^{-2}$ results in an elevation uncertainty of $\pm 10 \mathrm{~m}$ and $\pm 2 \mathrm{~m}$, respectively.

At the crust-mantle boundary (Moho) under the SCS, we have obtained a temperature of $700^{\circ} \mathrm{C}$ and a mantle heat flow of $24 \mathrm{~mW} \mathrm{~m}^{-2}$. For the north and south TB, at Moho depth, the temperature and the mantle heat flow decrease to $630^{\circ} \mathrm{C}$ and $25 \mathrm{~mW} \mathrm{~m}^{-2}$, and to $650^{\circ} \mathrm{C}$ and $27 \mathrm{~mW} \mathrm{~m}^{-2}$, respectively. The lithosphere-asthenosphere boundary $(L A B)$ is located at $99 \mathrm{~km}$ in the SCS and at $100 \mathrm{~km}$ and $\mathbf{9 5} \mathrm{km}$ in the north and south TB, respectively.

The differences between the coldest geotherm (North TB) and the hottest geotherm (SCS) remain almost constant, and even show a certain convergence of the curves in depth, indicating an effective lateral homogenization of the temperature in the sublithospheric mantle. Table 3 summarizes the values of the thermal models obtained in this study.

\subsection{Mechanical structure and strength envelopes}

Strength envelopes for the study area have been constructed using the geotherms presented in the previous section. For the SCS, two crustal brittle-ductile transitions (BDT) appear under tensional stress (Fig. 4), the upper BDT within the upper crust at a depth between 6 and $7 \mathrm{~km}$, depending on rheology, while the lower BDT is found in the middle crust at depth of $13 \mathrm{~km}$. On the other hand, under compression stress, the upper BDT depth is between 5 and $6 \mathrm{~km}$, but there is no BDT in the middle crust. In the case of the TB, a BDT appear within the upper crust but there is no BDT in the middle crust (Fig. 4). Under tensional stress, BDT is located at a depth between 6 and $10 \mathrm{~km}$, depending on rheology. Under compression stress, BDT depth is between 5 and $8 \mathrm{~km}$, depending on rheology. The lithospheric mantle remained in the ductile field for a wet peridotite rheology for the whole area (Fig. 4). For dry peridotite and tensional stresses, only the north TB presents a brittle portion in the lithospheric mantle with a BDT depth of $\sim 32 \mathrm{~km}$. Under compression conditions, the entire lithospheric mantle presents ductile behavior. Finally, all the strength envelopes show that the Moho always represents a strong mechanical discontinuity between the lower crust and the uppermost lithospheric mantle (Fig. 4). 


\begin{tabular}{|c|c|c|c|c|}
\hline & $\begin{array}{l}\text { Surface heat } \\
\text { flow }\left(\mathrm{mW} \mathrm{m}^{-2}\right)\end{array}$ & $\begin{array}{l}\text { Mantle heat } \\
\text { flow }\left(\mathrm{mW} \mathrm{m}^{-2}\right)\end{array}$ & $\begin{array}{l}\text { M॰h } \bullet \text { temperature } \\
(\bullet \mathrm{C})\end{array}$ & $\begin{array}{l}\text { Thermal lithospheric } \\
\text { thickness (km) }\end{array}$ \\
\hline Spanish Central System & 84 & 24 & 700 & 98 \\
\hline Tajo Basin (North) & 81 & 25 & 630 & 100 \\
\hline Ta jo Basin (South) & 83 & 27 & 650 & 95 \\
\hline
\end{tabular}

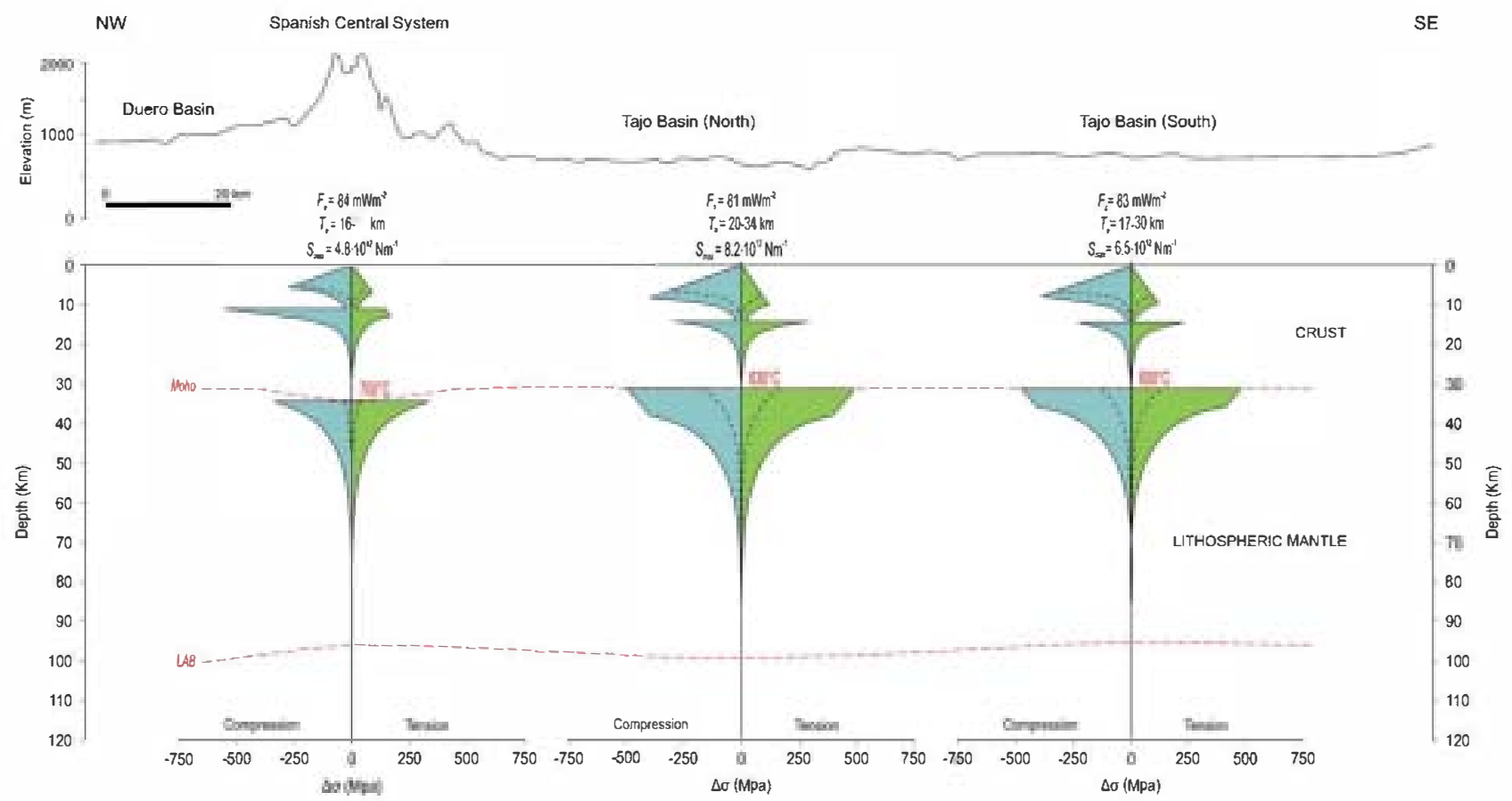

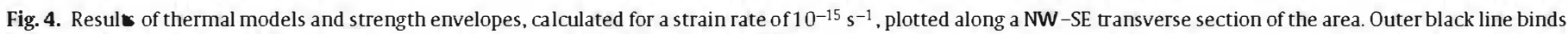

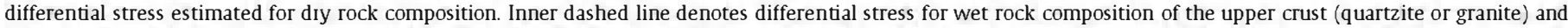

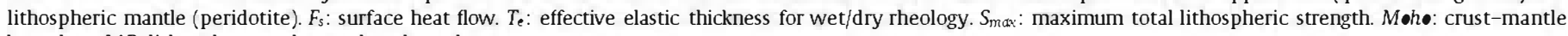
boundary. $L A B$ : lithosphere-asthenosphere boundary.

Fig. 5 shows total lithospheric strength for compressional and tensional stresses and, in each case, for dry and wet rheologies. Total strength ranges from $\sim 8.2 \times 10^{12}$ to $\sim 1.2 \times 10^{12} \mathrm{Nm}^{-1}$. In general, higher total lithospheric strengths are associated with the north TB, while minimum values corresponded to the SCS. These values are consistent with mean integrated strength values estimated under compressional conditions by Tesauro et al. (2009) for the continental lithosphere in Iberia. In the same way, the contribution of the lithospheric mantle to the total lithospheric strength ranges from $\sim 7 \times 10^{12}$ to $\sim 2 \times 10^{11} \mathrm{~N} \mathrm{~m}^{-1}$. These values are consistent with the wavelengths $(<250 \mathrm{~km}$ ) of the lithospheric folds, which suggests low mean mantle strength values $\left(<10^{13} \mathrm{~N} \mathrm{~m}^{-1}\right.$; Sokoutis et al., 2005), proposed by Muñoz-Martín et al. (2010) from the spectral

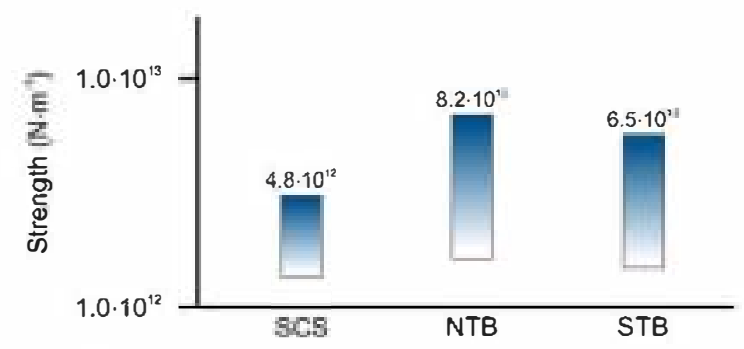

Fig. 5. Total lithospheric strength values for diy and wet rocks in compression and tension plotted for the different tectonic units. Higher strength values were obtained for diy rheology and compressive differential stress. Minimum strength values correspond to wet rheology and tensional differential stress. analysis of the gravity and elevation for continental lithosphere at the Africa-Eurasia boundary.

Our results can also be interpreted in term of the effective elastic thickness of the lithosphere $\left(T_{e}\right)$, a measure of the total strength of the lithosphere which integrates the contributions from brittle and ductile layers and from elastic cores of the lithosphere (for a review see Watts and Burov, 2003). We have calculated $T_{e}$ from the strength envelopes constructed for the SCS and the TB. Following Burov and Diament (1995), the total effective elastic thickness of an unflexed plate constituted by $n$ detached layers is

$T_{e}=\left(\sum_{i=1}^{n} t_{\mathrm{el}}^{3}\right)^{1 / 3}$.

where $t_{\boldsymbol{e} i}$ is the mechanical thickness of the layer $i$. We take the base of each mechanical layer as the depth in which the strength goes down to a value of $10 \mathrm{MPa}$ (see above). If strength levels at the base layer are higher than $10 \mathrm{MPa}$, the layer is considered welded to the layer below. The calculations were performed for both wet and dry rheology. For the SCS, the results are $16 \mathrm{~km}$ for wet rheology and $28 \mathrm{~km}$ for dry rheology. For the north and south TB, the obtained values are 17-20 and 30-34 km for wet and dry rheology, respectively. The lower values for the SCS are greatly resulting of the weaker upper mantle in this zone, which has a more limited contribution to the total strength of the lithosphere.

The effective elastic thickness depends on the thermal state of the lithosphere, which determines the thickness and contribution 
Van Wees et al. (1996)

Gómez-Ortiz et al. (2005a)

Pérez-Gussinyé and Watts (2005)

Ruiz et al. (2006)

Tesauro et al. (2007)

Martín-Velázquez et al. (2008)

This study

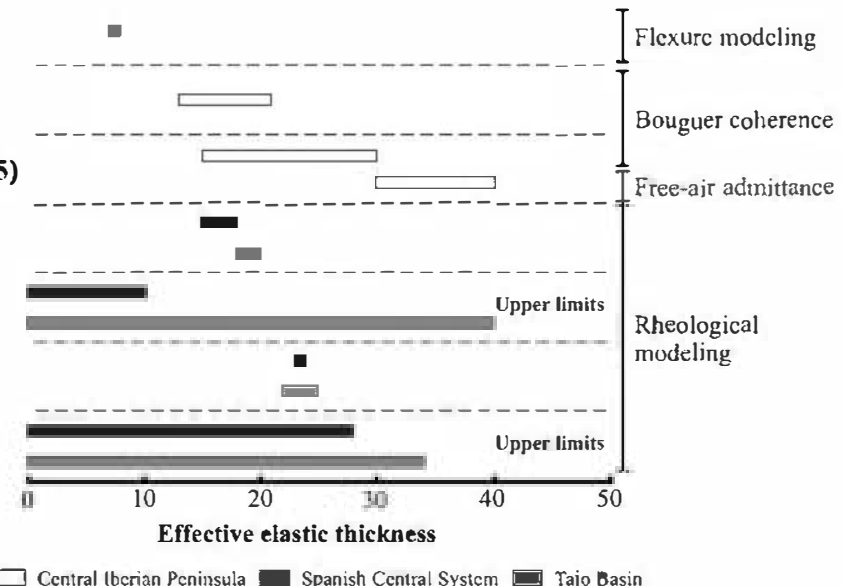

Fig. 6. Compilation of effective elastic thickness values obtained for the study area.
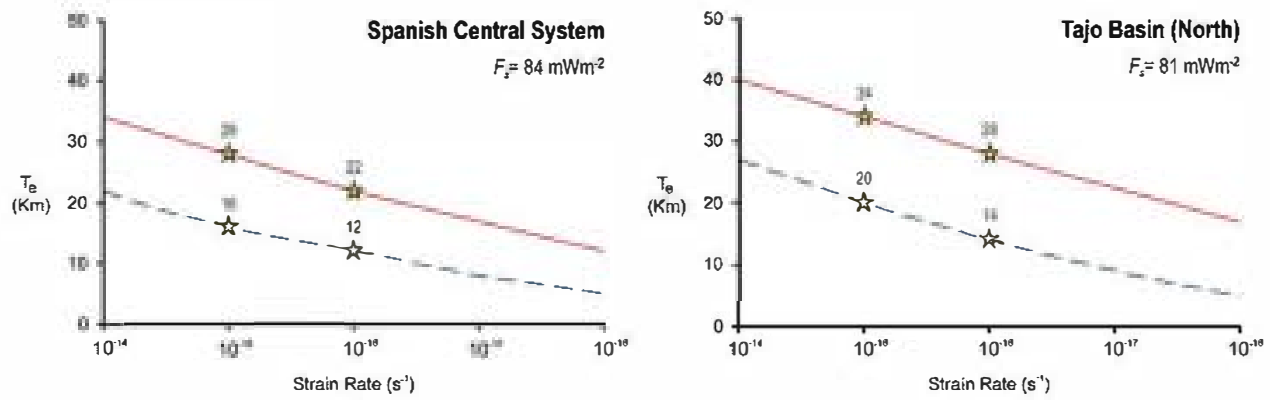

Diy lithology -- Wet lithology $T_{\mathbf{e}}$ values obtained from strengill envelopes

Fig. 7. Effective elastic thickness, in terms of strain rate, in the Spanish Central System and Tajo Basin (North). Diy and wet rheologies forthe crust and mantle are used in the calculation.

of mechanically competent layers, and on the local curvature of the plate (which in turn depends on the rheological structure and distribution of the external loads applied to the plate; e.g., Burov and Watts, 2006; Watts and Burov, 2003). Since curvature reduces the bending moment of the lithosphere, assuming an unflexed lithosphere our values of $T_{e}$ (obtained for dry rheology, which represent the maximum strength) can be considered upper limits.

Several works have focused on characterizing the lithospheric strength in the study area from estimating the effective elastic thickness of the lithosphere following different procedures (Fig. 6). Van Wees et al. (1996) calculated a value of $T_{e}$ of $7 \mathrm{~km}$ for the TB through flexure modeling, Gómez-ortiz et al. (2005a) obtained values of $14-21 \mathrm{~km}$ for the central Iberian Peninsula from the coherence between topography and Bouguer anomaly, and PérezGussinyé and Watts (2005) obtained best-fits of $15-30 \mathrm{~km}$ for the Iberian peninsula also from Bouguer coherence (but with the method of the free-air admittance these authors obtained higher $T_{e}$ values). Ruiz et al. (2006) used the relationship between rheology of the lithosphere and heat flow to calculate theoretical $T_{e}$ values of $18-20 \mathrm{~km}$ for the TB and 15-18 km for the SCS. The map of effective elastic thickness of the European lithosphere performed by Tesauro et al. (2007) shows an increase from $5-10 \mathrm{~km}$ in the SCS to $35 \mathrm{~km}$ within the basin. Tesauro et al. (2007) assumed an unflexed lithosphere, so their values of $T_{e}$ actually are upper limits as our results. For the TB, there is good correspondence between the values obtained by these authors and our results. Although for the case of SCS we obtain higher $T_{e}$ values. Finally, Martín-Velázquez et al. (2008), by means of a finite elements model, obtained an elastic thickness of $24 \mathrm{~km}$ for the SCS and $23-25 \mathrm{~km}$ for the TB (for wet and dry rheology, respectively).

\section{Discussion and conclusions}

In the present work we have used refined HPE values to obtain new estimates of heat production rates in the SCS and TB areas, which have been used joined to the relation between topography and thermal structure of the lithosphere to calculate the best-fit surface heat flows in the study area (see Sections 2 and 3). Moreover, we have implemented a temperature-dependent thermal conductivity (appropriate for olivine) for the lithospheric mantle to improve the calculations of temperature profiles in the mantle. The main influence of these procedures is that higher surface heat flows are needed to achieve similar temperatures at Moho depth, and small variations in surface heat flow have great influence in the temperature distribution within the lithosphere. The geotherms so obtained, together with the implementation of a new rheological law for the upper lithospheric mantle (see Section 4), have been used to calculate refined estimations of the strength and effective elastic thickness of the lithosphere. Thus, our results refine the thermo-mechanical models and lithospheric strength determinations for the study area.

Surface heat flow obtained for the north TB show good agreement with measurements of Fernàndez et al. (1998), which fall within the range between 62 and $94 \mathrm{~mW} \mathrm{~m}^{-2}$ with a mean value of $77 \pm 5 \mathrm{~mW} \mathrm{~m}^{-2}(n=6)$. In contrast, the south TB presents values of surface heat flow clearly higher than the observed range of values in that region (with a mean value of $48 \pm 7 \mathrm{~mW} \mathrm{~m}^{-2}$ for $n=6$, Fernàndez et al., 1998). This difference may be due to local effects. Surface heat flow determinations for the south TB were carried out on water, geothermal and mining explorations wells (Fernàndez et al., 1998). These wells can be affected by thermal 
disturbances due to water circulation (Marzán et al., 1996). In the south TB, geothermal gradient values observed are dispersed, and the thermal regime may be affected by surface water flow in porous levels and hydraulic connection between aquifers through the well (Marzán et al., 1996). Moreover, an average of $48 \mathrm{~mW} \mathrm{~m}^{-2}$ leads to an increase of the total lithospheric strength $\left(S \approx 1 \times 10^{15} \mathrm{~N} \mathrm{~m}^{-1}\right)$, and effective elastic thickness ( $T e \approx 150 \mathrm{~km}$ ), much higher than any previous estimates for the Central Iberian Peninsula (see Section 5.2).

Some authors use the mean value (and sometimes the median value) for the heat production rate in their models (e.g., Hasterok and Chapman, 2011). A heat production rate weighted by the areal distribution characterizes better our crust model that a purely statistical value, where less abundant rocks, but with higher sampling, would have greater weight in the calculations (see Table 2). We also consider a heat production rate weighted by the areal distribution more correct, therefore considering a radioactive heat sources homogeneously distributed. To check the influence on the results of our models, we have considered the effect of using mode values without taking into account the areal distribution of samples in order to study the model response. These slightly higher estimates of heat production rates $\left(2.6 \mu \mathrm{Wm}^{-3}\right.$ for the upper crust, and $1.1 \mu \mathrm{Wm}^{-3}$ for the lower crust), leads to an average increase of $4 \mathrm{~mW} \mathrm{~m}^{-2}$ in the surface heat flow, $20{ }^{\circ} \mathrm{C}$ of the temperature at the crust-mantle boundary(Moho), and enlarge $1 \mathrm{~km}$ in the thermal lithospheric thickness. In turn, the mantle heat flow is reduced by $1 \mathrm{~mW} \mathrm{~m}^{-2}$. This change in the thermal state, results in a decrease in $1 \mathrm{~km}$ of the $T_{e}$, and a reduction over $10-20 \%$ of the total lithospheric strength, depending on the stress regime. Thus, we consider our results robust.

In the case of the SCS, the crustal thickening (especially of the lower crust, which has a relatively high content of HPE; see Section 3), may be an important factor in its thermal structure. This thickening can be translated into a lithospheric mantle with a minor contribution in the calculation of surface heat flow, but proportionally hotter. So, the HPE-enriched and hot lower crust could reduce the heat loss from the lithospheric mantle. Recently, Boschi et al. (2010) and Faccenna and Becker (2010) have proposed the existence of a vigorous mantle upwelling in the western Mediterranean (from southern Iberia to the French Massif Central), based on interpreting residual topography (after correcting by isostasy) as dynamical topography due to mantle flow. In their models, the mantle upwelling would be driven by density variations caused by temperature differences derived from seismic tomography. However, thermal insulation of the upper mantle due to an HPE-enriched lower crust might be an important factor by contributing to mantle high temperatures. This state, together with an important contribution from crustal shortening and thickening, erosion during the endorheic-exorheic drainage transition, and lithospheric folding process (Casas-Sainz and De Vicente, 2009; De Vicente and Vegas, 2009; De Vicente et al., 2007, 2011; FernándezLozano et al., 2011) may be playing an important role in the uplift and maintenance of the SCS.

Moreover, the implementation of a new rheological law related to behavior of dry olivine in lithospheric conditions (see Section 4) results in a lithospheric mantle significantly weaker, with a consequent reduction of its contribution to the total effective strength. In the TB, the lithospheric mantle has a large contribution to the strength and the effective elastic thickness of the lithosphere. Consequently the strength of the mantle top would be in clear contrast with that of the weaker lower crust. Otherwise, the lithospheric mantle under the SCS is significantly weaker, clear reflection of its thermal state.

One non-well determined factor is the pore pressure. For crustal rocks, a hydrostatic pore fluid factor (equal to a column of water of height z) is usually assumed. In the absence of information pertaining to high temperature regimes and greater depths, the pore fluid factor is usually taken uniform for the whole lithosphere (e.g., Afonso and Ranalli, 2004; Mahatsente et al., 2012; Tesauro et al., 2009). In this study, the pore pressure is assumed as 0.37 (see Section 4). Previous works have assumed a hydrostatic pore fluid factor for the study area, ranging from 0.36 to 0.4 (Ruiz et al., 2006; Tejero and Ruiz, 2002; Tesauro et al., 2009). This range leads to a variation of the total lithospheric strength over $1-4 \%$ depending on stress regimen. In addition, if an increase of the pore fluid factor to values of 0.6 and 0.8 is considered in order to simulate the presence of super-hydrostatic pressures, leads to a decrease of the total lithospheric strength over $15-25 \%$ and $40-50 \%$ depending on stress regimen, respectively. This pattern is similar to that observed by Tesauro et al. (2009). It must be noted that pore fluid pressure reduces brittle strength, and hence increases temperature at the BDT depth ( Ruiz et al., 2011).

On the other hand, the ductile strength is largely strain rate dependent. As in previous works (e.g., Martín-Velázquez et al., 2008; Ruiz et al., 2006; Tejero and Ruiz, 2002), our strength envelopes are here calculated for a strain rate of $10^{-15} \mathrm{~s}^{-1}$, but other authors consider a value of $10^{-16} \mathrm{~s}^{-1}$ as a characteristic strain rate value for intraplate Europe (Tesauro et al., 2007). Fig. 7 shows the effective elastic thickness calculated for the SCS and TB in terms of strain rate. If we considered a strain rate of $10^{-16} \mathrm{~s}^{-1}$, the results are $12-22 \mathrm{~km}$ and $14-28 \mathrm{~km}$, respectively for the SCS and the TB (depending on wet or dry rheology). Other of the main uncertainties could be due to not considering the effect of the horizontal regional stresses, which could have a strong effect on the $T_{e}$ (Cloetingh and Burov, 1996).

Finally, future investigations should also consider other important influences on the rheological properties of major silicate rocks. For example, oxygen fugacity under anhydrous conditions (Keefner et al., 2011) or water fugacity under water-saturated conditions (Katayama and Karato, 2008) could significantly affect upper mantle rheology. This kind of consideration further will constrain the mechanical behavior of lithospheric materials, and their implications for the thermal and mechanical state of the lithosphere.

\section{Acknowledgements}

The authors would like to thank the Editor Randell Stephenson and two anonymous reviewers for their comprehensive revision and comments, which were of great help in the preparation of the final version of this paper. We also thank Giorgio Ranalli and Alfonso Muñoz Martín for their useful comments and suggestions that helped to improve the manuscript and Viazmelya Monroy for her assistance with the English language of this article. AJ-D was supported by a grant of the Complutense University of Madrid (Spain). JR was supported by a contract Ramón y Cajal cofinanced from the Ministerio de Ciencia e Innovación of Spain and the Fondo Social Europeo (ESF). This work was carried out in the projects CGL2008-03463, CGL2008-05952 and CGL2009-14405-C02-02 of the Ministerio de Ciencia e Innovación of Spain and the GR35/10A-910492-UCM.

\section{References}

Afonso, J.C., Ranalli, G., 2004. Crustal and mantle strengths in continental lithosphere: is the jelly sandwich model obsolete? Tectonophysics 394, 221-232.

Banda, E., Suriñach, E., Aparicio, A., Sierra, J., Ruiz de la Parte, E., 1981. Crust and upper mantle structure of the central Iberian Meseta (Spain). Geophys. J. Int. 67. 779-789.

Boschi, L., Faccenna, C., Becker, T.W., 2010. Mantle structure and dynamic topography in the Mediterranean Basin. Geophys. Res. Lett. 37, L20303, doi: 10.1029/2010GL045001.

Brace, W.F., Kohlstedt, D.L., 1980. Limits on lithospheric stress imposed by laboratory experiments. J. Geophys. Res. 94, 3967-3990. 
Biirgmann, R., Dresen, G., 2008. Rheology of the lower crust and upper mantle: evidence from rock mechanics, geodesy, and filed observations. Annu. Rev. Earth Planet. Sci. 36, 531-567, doi:10.1146/annurev.earth.36.031207.124326.

Burov, E.B., Diament, M., 1995. The effective elastic thickness of (Te) continental lithosphere. What does it really means? J. Geophys. Res. 100 (B3), 3905-3927.

Burov, E.B., Watts, A.B., 2006. The long-term strength of continental lithosphere: jelly sandwich or crème brûlée? GSA Today $16(1), 4-10$.

Casas-Sainz,A.M., De Vicente,G., 2009. On the tectonic origin of Iberian topography. Tectonophysics 474, 214-235, doi: 10.1016 j j.tecto. 2009.01 .030

Chapman, D.S., Furlong, K.P., 1992. Thermal state of continental lower crust. In: Fountain, D.M., Arculus, R., Kay, R.W. (Eds.), Continental Lower Crust. Elsevier Science, Amsterdam, pp. 179-199.

Chopra, P.N., Paterson, M.S., 1984 The role of water in the deformation of dunite. J. Geophys. Res. 89, 7861-7876.

Cloetingh, S.E.B., Burov, E.B., 1996. Thermomechanical structure of European continental lithosphere: constraints from rheological profiles and EET estimates Geophys. J. lnt. 124, 695-723.

De Vicente, G., Cloetingh, S., Van Wees, J.-D., Cunha, P.P., 2011. Tectonic classification of Cenozoic Iberian foreland basins. Tectonophysics 502, 38-61.

De Vicente, G., Vegas, R., Muñoz-Martín, A., Van Wees, J.D., Casas-Sáinz, A., Sopeña, A., Sánchez-Moya, Y., Arche, A., López-Gómez, J., Olaiz, A., Fernández-Lozano, J., 2009. Oblique strain partitioning and transpression on an inverted rift The Castilian Branch of the Iberian Chain. Tectonophysics 470, 224-242.

De Vicente, G., Vegas, R., 2009. Large-scale distributed deformation controlled topography along the western Africa-Eurasia limit: tectonic constrains Tectonophysics 474, 124-143.

De Vicente, G., Vegas, R., Muñoz Martín,A., González-Casado, J.M., Carbó,A., Álvarez, J., Cloetingh, S., Andriessen, P., Elorza, F. J., Olaiz, A., 2004. Estructura alpina del Antepaís lbérico. Cadenas sin cobertera. El Sistema Central. In: Vera,J.A. (Ed.), Geología de España. SGE-IGME, Madrid, pp. 621-626.

De Vicente, G., Vegas, R., Muñoz Martín, A., Silva, P.G., Andriessen, P., Cloetingh, S., González Casado, J.M., Van Wees, J.D., Álvarez, J., Caıbó, A., Olaiz, A., 2007 Cenozoic thick-skinned deformation and topography evolution of the Spanish Central System. Global Planet. Change 58, 335-338.

Faccenna, C., Becker, T.W., 2010. Shaping mobile belts by smallscale convection Nature 465, 602-605, doi: 10.1038 /nature09064.

Fernàndez, M., Marzám, I., Correia, A., Ramalho, E., 1998. Heat flow, heat production, and lithospheric thermal regime in the Iberian Peninsula. Tectonophysics 291, 29-53.

Femández-Lozano, J., Sokoutis, D., Willingshofer, E., Cloetingh, S., De Vicente, G., 2011. Cenozoic deformation of Iberia: a model for intraplate mountain building and basin development based on analogue modeling. Tectonics 30, TC1001, doi:10.1029/2010TC002719.

Furlong, K.P., Chapman, D.S., 1987. Crustal heterogeneities and the thermal structure of the continental crust Geophys. Res. Lett. 14, 314-317.

Gómez-Ortiz, D., Tejero, R., Ruiz, J., Babín-Vich, R., González-Casado, J.M., $2005 a$. Estimating the effective elastic thickness of the Iberian Peninsula's lithosphere based on multitaper spectral analysis. Geophys. J. Int. 160, 729-735.

Gómez-Ortiz, D., Tejero-López, R., Babín-Vich, R., Rivas-Ponce, A., 2005 b. Crustal density structure in the Spanish Central System derived from gravity data analysis (central Spain). Tectonophysics 403, 131-149, doi: $10.1016 /$ j.tecto.2005.04.006.

Hasterok, D., Chapman, D., 2007. Continental thermal isostasy. I: methods and sensitivity. J. Geophys. Res. 11, 2, doi:10.1029/2006JB004663.

Hasterok, D., Chapman,D., 2011. Heat production and geotherms for the continental lithosphere. Earth Planet. Sci. Lett., doi:10.1016/j.epsI.2011.04.034

Hofmeister, A.M., 1999. Mantle values of thermal conductivity and the geotherm from phonon lifetimes. Science 283, 1699-1706.

IGME-ENRESA, 1998. Neotectonic Map of Spain Sc: 1/1.000.000 (J. Baena, Coord.) Madrid, Spain.

ILIHA DSS Group, 1993. A deep seismic sounding investigation of the lithospheric heterogeneity and anisotropy beneath the Iberian Peninsula. Tectonophysics $221,35-51$.

Katayama, I., Karato, S.-I., 2008. Low-temperature, high-stress deformation of olivine under water-saturated conditions. Phys. Earth Planet. Inter. 168, 125-133, doi: $10.1016 /$ j.pepi.2008.05.019

Keefner, J.W., Mackwell,S. J., Kohlstedt, D.L., Heidelbach, F., 2011. Dependence of dis location creep of dunite on oxygen fugacity: implications for viscosity variations in Earth's mantle. J. Geophys. Res. 116, B05201, doi: 10.1029/2010JB007748.

Kohlstedt, D.L., Evans, B., Mackwell, S. J., 1995. Strength of the lithosphere: constraints imposed by laboratory experiment. J. Geophys. Res. 100, 17587-17602.

Lachenbruch,A.H., Morgan, P., 1990. Continental extension, magmatism and elevation; formal relations and rules of thumb. Tectonophysics 174,39-62.

Mahatsente, R., Ranalli, G., Bolte, D., Götze, H.-J., 2012. On the relation between lithosphericstrength and ridge push transmission in the Nazca plate. J. Geodyn. 53, 18-26, doi: $10.1016 /$ j.jog.2011.08.002.

Martín-Velázquez, S., De Vicente, G., Elorza, F. J., 2008. Resistencia, espesor elástico efectivo y deformación de la litosfera lbérica (Sistema Central y cuencas del Duero y Tajo). Geo-Temas 10, 1523-1526.
Martín-Velázquez, S., De Vicente, G., Elorza, F.J., 2009. Intraplate stress state from finite element modelling: the southern border of the Spanish Central System. Tectonophysics 473, 417-427.

Marzán, I., Fernández, M., Cabal, J., 1996. Estudio geotérmico en la mitad Occidental de España. Geogaceta 20, 745-748.

McKenzie, D., Jackson, J., Priestley, K., 2005. Thermal structure of oceanic and continental lithosphere. Earth Planet. Sci. Lett. 233,337-349.

McNutt, M.K., 1984. Lithospheric flexure and thermal anomalies. J. Geophys. Res. 89, $11180-11194$.

Mei, S., Suzuki, A.M., Kohlstedt, D.L., Dixon, N.A., Durham, W.B., 2010. Experimental constraints on the strength of the lithospheric mantle. J. Geophys. Res. 115, B08204, doi: $10.1029 / 2009$ JB006873.

Muñoz-Martín, A., De Vicente, G., Fernandez-Lozano, J., Cloetingh, S., Willingshofer, E., Sokoutis, D., Beekman, F., 2010. Spectral analysis of the gravity and elevation along the westem Africa-Eurasia plate tectonic limit: continental versus oceanic lithospheric folding signals. Tectonophysics $495,298-314$ doi:10.1016/j.tecto.2010.09.036, ISSN 0040-1951.

Pérez-Gussinyé, M., Watts, A.B., 2005. The long-term strength of Europe and its implications for plate-forming processes. Nature 436, doi: $10.1038 /$ nature 03854

Ranalli,G., 1994. Nonlinearflexure and equivalent mechanical thickness of the lithosphere. Tectonophysics 240, 107-114.

Ranalli, G., 1997. Rheology of the lithosphere in space and time. Geol. Soc. Spec. Pub. 121,19-37

Ranalli,G., Murphy,D.C., 1987. Rheological stratification of the lithosphere. Tectonophysics $132,281-295$

Rudnick, R.L., Gao, S., 2003. Composition of the continental crust. In: Rudnick, R.L. (Ed.), The Crust (In: Holland, H.D., Turekian, K.K.(Eds.), Vol. 3 Treatise of Geochemistry. Elsevier-Pergamon, Oxford, pp. 1-64.

Ruiz, J., Gómez-Ortiz, D., Tejero, R., 2006. Effective elastic thicknesses of the lithosphere in the Central Iberian Peninsula from heat flow: implications for the rheology of the continental lithospheric mantle. J. Geodyn. 41, 500-509.

Ruiz,J., McGovem, P.J., Jiménez-Díaz,A., López,V., Williams, J.-P., Hahn, B.C., Te jero, R., 2011. The thermal evolution of Mars as constrained by paleo-heat flows. lcarus 215, 508-517, doi:10.1016/j.icarus.2011.07.029.

Rybach, L. 1988. Determination of heat production rate. In: Haenel, R., Rybach, L. Stegena, L. (Eds.), Handbook of Terrestrian Heat-flow Density Determination. Kluwer, pp. 125-142.

San José, M.A., Pieren, A., García-Hidalgo, J.F., Vilas, L., Herranz,P.,Peláez,J.R., Perejón, A., 1990. Ante-Ordovician Stratigraphy. Authocthonous sequences of CentralIberian Zone. In: Dallmayer, R.D., Martínez-García, E. (Eds.), Pre-Mesozoic Geology of Iberia. Springer-Verlag, Berlín, pp. 145-159.

Sibson, R.H., 1974. Frictional constraints on thrust, wrench and normal faul $\mathbf{s}$. Nature $249,542-544$

Sokoutis, D., Burg, J.P., Bonini, M., Corti, G., Cloetingh, S., 2005. Lithospheric-scale structures from the perspective of analogue continental collision. Tectonophysics 406, 1-15.

Stiiwe, K., 2002. Geodynamics of the Lithosphere. An Introduction. Springer-Verlag, Berlin, p. 449.

Suriñach, E., Vegas, R., 1988. Lateral inhomogeneities of the Hercyninan crust in central Spain. Phys. Earth Planet Inter. 51, 226-234.

Tejero, R., Ruiz, J., 2002. Thermal and mechanical structure of the central Iberian Peninsula lithosphere. Tectonophysics 350, 49-62.

Tesauro, M., Kaban, M.K., Cloetingh, S., 2009. A new thermal and rheological model of the European lithosphere. Tectonophysics 476, 478-495.

Tesauro, M., Kaban, M.K., Cloetingh, S., Hardebol, N. J., Beekman, F., 2007. 3D strength and gravity anomalies of the European lithosphere. Earth Planet. Sci. Lett. 263. $56-73$.

Van Wees, J.D., Cloetingh, S., de Vicente, G., 1996. The role of pre-existing faults in basin evolution: constraints from 2D finite element and 3D flexure models. Geol. Soc. Spec. Pub. 99, 297-320

Vilà, M.,Fernández,M., Jiménez-Munt, I., 2010. Radiogenic heat production variability of some common lithological groups and its significance to lithospheric thermal modeling. Tectonophysics 490, 152-164, doi: 10.1016/j.tecto.2010.05.003, ISSN: 0040-1951

Villaseca, C., Barbero, L., Rogers, G., 1998. Crustal origin of Hercynian peraluminous granitic batholiths of Central Spain: petrological, geochemical and isotopic ( $\mathrm{Sr}$, Nd) constraints. Lithos 43, 55-79.

Villaseca, C., Downes, H., Pin, C., Barbero, L., 1999. Nature and composition of the lower continental crust in central Spain and the granulite-granite linkage: inferences from granulitic xenoliths. J. Petrol. 40, 1465-1496.

Villaseca, C., Ore jana, D., Pérez-Soba, C., Reyes, J., 2005. Estimación del régimen térmicoy producción de calor de los niveles litosféricos del Sis tema Central Español. Geogaceta 38, 215-218

Watts,A.B., Burov, E.B., 2003. Lithospheric strength and it relation to the elastic and seismogenetic layer thickness. Earth Planet Sci. Lett. 213,113-131. 